\title{
DETERMINATION OF POSTHARVEST QUALITY OF PORANG (AMORPHOPHALLUS MUELLERI BLUME) TUBERS BASED ON THE DYNAMICS OF WEIGHT LOSS, WATER CONTENT AND CARBOHYDRATE COMPONENTS FOR THE PHARMACEUTICAL INDUSTRY
}

\author{
DWI GUSMALAWATI ${ }^{1,2,3}$, ESTRI LARAS ARUMINGTYAS ${ }^{2,3}$, RETNO MASTUTI ${ }^{2}$, RODIYATI \\ AZRIANINGSIH ${ }^{2,3 *}$ \\ ${ }^{1}$ Biology Department, Faculty of Mathematics and Natural Sciences, Tanjungpura University, Jalan A. Yani, Pontianak \\ 78124, Indonesia \\ ${ }^{2}$ Biology Department, Faculty of Mathematics and Natural Sciences, Brawijaya University, Jalan Veteran, Malang 65145, \\ Indonesia \\ ${ }^{3}$ Porang Research Center (PRC) Brawijaya University, Jalan Veteran, Malang 65145, Indonesia
}

*corresponding author: rodiyati@ub.ac.id

Manuscript received: February 2021

\begin{abstract}
This study aims to assess the quality of postharvest porang tubers based on the dynamics of weight loss, moisture content, and carbohydrate components for the pharmaceutical industry. We measured the weight loss, water content, and carbohydrate component every two weeks for 20 weeks postharvest (PW). Postharvest tuber weight loss increased significantly to $30.27 \%$, followed by a decrease in water content to $75.94 \%$. HPLC analysis on postharvest porang tubers successfully identified nine carbohydrate components: xylose, arabinose, rhamnose, glucose, galactose, mannose, trehalose, mannan, and glucomannan. Age of postharvest tubers had a significant effect on changes in carbohydrate components concentration because glucomannan had the highest concentration compared to other carbohydrate components at $20 \mathrm{PW}$. Glucomannan concentration was increased to $116 \mathrm{mg} / \mathrm{g}$ at $10 \mathrm{PW}$ but decreased to $90 \mathrm{mg} / \mathrm{g}$ at $20 \mathrm{PW}$. Mannan, lower than glucomannan, showed a similar pattern, rising to a maximum of $93.17 \mathrm{mg} / \mathrm{g}$ at $8 \mathrm{PW}$ and then decreased to $51.33 \mathrm{mg} / \mathrm{g}$ at $20 \mathrm{PW}$. Xylose, arabinose, rhamnose, and trehalose concentrations were very small, with less than $8.87 \mathrm{mg} / \mathrm{g}$ also continued to decrease until the age of $20 \mathrm{PW}$. Conversely, the concentration of carbohydrate components, glucose, galactose, and mannose increased until the age of $20 \mathrm{PW}$. Increased weight loss, decreased water content, and increased or decreased concentrations of carbohydrate components in postharvest porang tubers were related to respiration and transpiration activity. Based on those findings, it is suggested that the best time for processing porang tubers as pharmaceutical industry materials is no more than $10 \mathrm{PW}$.
\end{abstract}

\section{Rezumat}

Acest studiu își propune să evalueze calitatea tuberculilor de porang postrecoltare pe baza dinamicii pierderii de masă, a conținutului de apă şi de carbohidrați, pentru utilizarea în industria farmaceutică. S-au măsurat pierderea de masă, conținutul de apă și carbohidrați la fiecare două săptămâni timp de 20 de săptămâni după recoltare (PR). Pierderea de masă a tuberculilor după recoltare a crescut semnificativ la 30,27\%, urmată de o scădere a conținutului de apă la 75,94\%. Analiza HPLC a tuberculilor de porang după recoltare a identificat cu succes nouă componente din categoria carbohidraților: xiloză, arabinoză, ramnoză, glucoză, galactoză, manoză, trehaloză, manan și glucomanan. Vârsta tuberculilor după recoltare a avut un efect semnificativ asupra modificărilor concentraţiei de carbohidrați, deoarece glucomananul a avut cea mai mare concentrație în comparaţie cu alţi carbohidraţi la 20 PR. Concentrația de glucomanan a crescut la $116 \mathrm{mg} / \mathrm{g}$ la $10 \mathrm{PR}$, dar a scăzut la $90 \mathrm{mg} / \mathrm{g}$ la $20 \mathrm{PR}$. Mananul, în concentrație mai mică decât glucomananul, a prezentat un model similar, crescând la un maxim de 93,17 mg/g la 8 PR și apoi a scăzut la 51,33 mg/g la 20 PR. Concentrațiile de xiloză, arabinoză, ramnoză și trehaloză au fost foarte mici, cu mai puțin de 8,87 mg/g, de asemenea, au continuat să scadă până la 20 PR. În schimb, concentrația de componente carbohidrate, glucoză, galactoză și manoză a crescut până la 20 PR. Creșterea pierderii de masă, scăderea conținutului de apă şi creșterea sau scăderea concentrațiilor de carbohidrați în tuberculii de porang postrecoltare au fost legate de activitatea de respirație și transpirație. Pe baza acestor constatări, se sugerează că cel mai bun moment pentru procesarea tuberculilor de porang ca materie primă pentru industria farmaceutică este de sub 10 PR.

Keywords: biochemistry, glucomannan, pharmacy, postharvest

\section{Introduction}

Porang (Amorphophallus muelleri Blume) belongs to the family of Araceae, which is widely found in India, Myanmar, Thailand, and Indonesia [14, 42]. This perennial herb has four growing periods in its life cycle. Generally, the tubers used as an industrial material were harvested from plants in the third growing period because they have the highest concentrations 
of glucomannan [16, 37, 38]. Glucomannan is a carbohydrate (polysaccharides) consisting of two monosaccharides (mannose and glucose). It has many valuable ingredients in the pharmaceutical, food, cosmetics, textile and other industries [41, 43]. The carbohydrate component is one of the reference components to determine the quality of tubers as an industrial material [20]. However, the carbohydrate component in postharvest tubers changes due to metabolic activity, decreasing the quality of tubers as foodstuffs and pharmaceuticals [31].

During postharvest, porang tubers have a 16-week dormancy period [21,38]. Within this period, the activity of growth, development, metabolism run slowly, and food reserves do not run out quickly, so the quality of tubers is very good for food $[11,12]$. The dormancy period is influenced by internal factors (genetic, hormonal, respiration and transpiration) and external (temperature, humidity and injury) [10, 27, 30]. It (external and internal factors) also determines the end of the period of dormancy and is marked by the emergence of sprouts. In postharvest tubers of Dioscorea, which are placed at room temperature, the respiration rate during the dormancy period is lower than when buds sprout. A high respiration rate in the tuber during the emergence of this sprout causes a lot of water loss, resulting in weight loss. In addition to respiration, transpiration also causes postharvest Colocasia tubers to undergo a severe decrease $(28 \%)$ due to reduced water content $(7.31 \%)$, thereby reducing the quality of tubers as food [19, 32, 36]. In postharvest sweet potatoes, starch concentrations decrease due to endogenous amylolytic enzyme activity [44]. The amylase enzyme serves to hydrolyse the starch granules to simple sugars as an energy source that promotes embryo growth [25]. However, the transformation of starch into simple postharvest sugars causes nutrients in the tubers as food. Proper postharvest handling needs to be performed to reduce starch reduction (which causes a decrease in nutrition) [31].

Research on postharvest porang tubers is still very limited. This information is necessary to control the quality of tubers for industrial material. Factors causing a decrease in tuber quality can be measured by water content, weight loss and carbohydrate components in postharvest tubers. Therefore, the purpose of this study was to determine the quality of postharvest porang tubers based on the dynamics of weight loss, water content and carbohydrate components. So, our study leads to the detection of the quality of tubers for the pharmaceutical industry based on postharvest age.

\section{Materials and Methods}

Tuber sample

Our study used porang tubers from the porang plantation in Rejosari Village, Bantur, Malang and East Java, Indonesia. Porang tubers were harvested from plants in the third growing period when the petioles and leaves were dried and released from the tubers. The total harvested tubers were 66 pieces, each weighing around $600-1800 \mathrm{~g}$. Tubers was placed on a bamboo rack in a room with a temperature of $23-30^{\circ} \mathrm{C}$ and humidity of $49-69 \%$. The first day of harvest was set as 0 PW tuber age. Furthermore, the weight loss, water content and carbohydrate component levels were measured every two weeks for 20 weeks.

Determination of weight loss

The initial and final weights of the tuber were measured using a digital scale. Weight loss percentage was calculated by the difference between the initial and final weight of the tuber divided by the initial weight multiplied by $100 \%$ [7].

\section{Determination of Water Content}

Tuber water content was measured by the oven drying method. Briefly, $10 \mathrm{~g}$ of fresh tubers was taken, then settled in the oven at $105^{\circ} \mathrm{C}$ for $24 \mathrm{~h}$. The dried tuber was then placed into the desiccator for $15 \mathrm{~min}$ and then weighed. The formula to calculate the percentage of tuber water content is the difference in the initial weight of the tuber before dried in the oven and the final weight after being removed from the oven divided by the initial weight multiplied by $100 \%$ [7].

Determination of carbohydrate components using HPLC Method

Preparations of carbohydrate standard

Summarily, the standard carbohydrates stock solution is prepared by dissolving $50 \mathrm{mg}$ of standard carbohydrates (Sigma Aldrich) into distilled water to 1000 $\mathrm{mL}(50 \mathrm{mg} / \mathrm{L})$. Five different concentrations of solutions were adjusted with a concentration $(\mathrm{mg} / \mathrm{L}) 0,0.1,0.5$, $1,2.5$, and 5. Furthermore, the dilution can be used to determine the standard curve equation.

Sample preparation

One $\mathrm{g}$ of the tuber sample was crushed until smooth. Additionally, $80 \mathrm{~mL}$ of warm distilled water (temperature $80^{\circ} \mathrm{C}$ ) was added and stirred until homogenous. The sonication was performed for $15 \mathrm{~min}$. The extract was stored in a refrigerator at $4^{\circ} \mathrm{C}$ for $30 \mathrm{~min}$ and diluted with distilled water to a volume of $100 \mathrm{~mL}$. Then, solution was subsequently poured into column C18 Sep-Pak to remove fat, protein, and other solids. Last, the solution was set for HPLC analysis after relieving the effluent.

\section{HPLC Analysis}

The standard and sample solutions were filtered with a $0.45 \mu \mathrm{m}$ membrane filter before injecting into an HPLC device. HPLC analysis was carried out using Shimadzu with CBM 20 system controller, solvent delivering LC 20AT unit, and CTO 20 A. Column oven HPLC was set with RID 20-A Refractive index detector parameters, column Shim-pack ISA $7 \mu \mathrm{m}(4$ $\mathrm{mm} \times 25 \mathrm{~cm}$ ) on column temperature of $25^{\circ} \mathrm{C}$. The mobile phase used acetonitrile: water 75:25 (v/v) with the isocratic mobile phase method at a $0.9 \mathrm{~mL} / \mathrm{min}$ flow rate. The volume of injected extract was $10 \mu \mathrm{L}$ 
and operated within $40 \mathrm{~min}$. Carbohydrate component levels were calculated using HPLC software: Shimadzu LC Solution Version 5.6.1. for Windows [35].

\section{Method validation}

In this study, the validation test was carried out, namely the linear regression equation parameters and the coefficient of determination based on standard curves. The linear regression equation was calculated from the calibration curve. Linear regression equation and the coefficient of determination on xylose: $\mathrm{Y}=$ $3.5896+8.6193 X, R^{2}=0.968$; arabinose: $Y=3.7018+$ 8.3802X, $\mathrm{R}^{2}=0.957$; rhamnose: $\mathrm{Y}=3.6682+8.3488 \mathrm{X}$, $\mathrm{R}^{2}=0.963$; glucose: $\mathrm{Y}=3.8303+8.3103 \mathrm{X}, \mathrm{R}^{2}=0.954$; galactose: $\mathrm{Y}=3.7607+8.8548 \mathrm{X}, \mathrm{R}^{2}=0.964$; mannose: $\mathrm{Y}=3.7518+8.3583 \mathrm{X}, \mathrm{R}^{2}=0.959$ trehalose: $\mathrm{Y}=3.6769+$ 8.4235X, $R^{2}=0.965$; mannan: $Y=3.7568+8.4866 X$, $\mathrm{R}^{2}=0.962$, and glucomannan: $\mathrm{Y}=3.5908+8.5689 \mathrm{X}$, $R^{2}=0.964$, respectively. All linear regression equations for carbohydrate components have a coefficient of determination $\left(\mathrm{R}^{2}\right)$ greater than 0.954 , indicating that the equation is fit very well.

Statistic analysis

The weight loss, water content and carbohydrate component were analysed using One-way ANOVA and continued with the Tukey test at $\alpha=0.05$. The relationship between variables was analysed using the Bivariate Correlation test. All data were analysed using SPSS Statistics version 16.0. This research was conducted in 6 replicates.

\section{Results and Discussion}

The dynamics of weight loss and water content of postharvest porang tubers

The age of postharvest porang tubers was affected significantly $(\mathrm{p}=0.05)$ on weight loss and water content. Tuber weight loss in the $2^{\text {nd }}$ week was $6.35 \%$, and it increased until the $20^{\text {th }}$ week to $30.27 \%$. A decrease followed the increase in weight loss in water content. The initial tuber water content was $83.19 \%$ and decreased until the $20^{\text {th }}$ week to $75.94 \%$ (Figure 1). The older the postharvest porang tubers, the greater the weight loss and the lower the water content. Increased weight loss and decreased water content in postharvest porang may be influenced by the process of respiration and transpiration.

During postharvest, the tubers undergo a dormancy period to anticipate unfavourable environmental conditions [40]. In this dormancy period, the activity of tuber metabolism is not active; however, metabolic processes such as respiration and transpiration continue to maintain growth potential in the next phase [3,5]. Respiration involves the oxidation process, whereas carbohydrates (sugars) are converted into water, carbon dioxide, and heat energy at the cellular pathway. The metabolic of starch conversion into sugar causes the decrease of tuber's dry matter. Transpiration is the process of evaporation of water through the skin of the tubers.
Postharvest tubers' rate of respiration and transpiration is influenced by postharvest age as indicated by weight loss and water content [2, 11, 40]. Respiration and transpiration rates will decrease after the tubers are harvested, begin the dormancy period and then increase again during sprouting [11, 32]. In Colocasia tubers, weight loss increased by $95 \%$ until the age of $20 \mathrm{PW}$. Besides being influenced by the age of postharvest tubers, the increase in weight loss was controlled by the rate of respiration and transpiration, the degree of tuber rot, temperature and relative humidity, so that the tubers can no longer be consumed (at that age) [19].

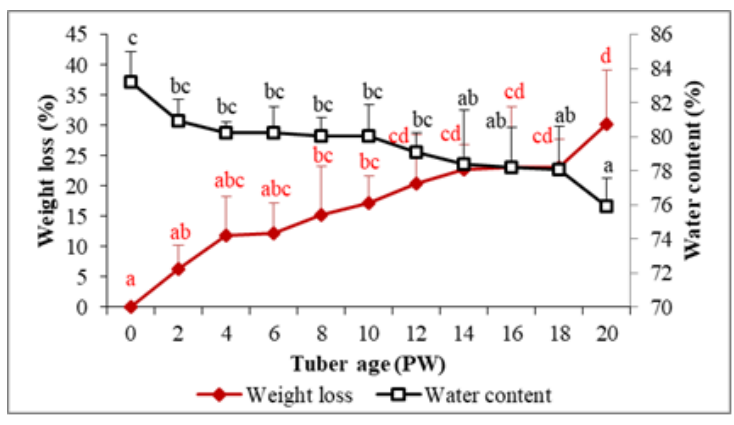

Figure 1.

Weight loss and water content in postharvest porang tubers

PW: postharvest week, the same letter notation (a, b, c and d) on each variable shows no significant difference $(p=0.05)$, bar $=$ standard error $(\mathrm{SE})$

The dynamics of the carbohydrate component in postharvest porang tubers

HPLC analysis on postharvest porang tubers showed nine carbohydrate components (xylose, arabinose, rhamnose, glucose, galactose, mannose, trehalose, mannan and glucomannan). Six carbohydrate components (xylose, arabinose, rhamnose, glucose, galactose and mannose) were simple sugars. At the same time, the three carbohydrate components (trehalose, mannan and glucomannan) belong to complex sugars. Glucomannan is composed of glucose and mannose, whereas mannan is composed of 2 mannose molecules [8]. Trehalose is a disaccharide consisting of 2 glucose molecules [4]. In Arabidopsis, xylose, arabinose, glucose, galactose, mannose and other sugars were constituent components of hemicellulose, a mixture of polysaccharides in which the biomass was the most abundant after cellulose [23]. This carbohydrate component controls plant growth and development, many of which accumulate in cell walls. In the industrial field, this carbohydrate component is essential for food and medicine [9].

ANOVA test showed that the age of postharvest tubers had a significant effect $(\mathrm{p}=0.05)$ on the concentrations of each carbohydrate component in porang tubers. The concentration of nine components of carbohydrates was different at each different postharvest age. After 20 PW observations, some carbohydrate component concentrations increased, while 
some of them decreased. Twenty weeks after harvesting, the carbohydrate component with the highest concentration was glucomannan. The concentration increases to 116 $\mathrm{mg} / \mathrm{g}$ at $10 \mathrm{PW}$, then decreases to $90 \mathrm{mg} / \mathrm{g}$ at $20 \mathrm{PW}$. Mannan, which was lower than glucomannan, showed a similar pattern continued to increase to $93.17 \mathrm{mg} / \mathrm{g}$ at $8 \mathrm{PW}$ and then decrease to $51.33 \mathrm{mg} / \mathrm{g}$ at $20 \mathrm{PW}$. Xylose and rhamnose had lower concentrations than glucomannan, but had the same pattern as glucomannan, their concentrations increased to 8.84 and $6.04 \mathrm{mg} / \mathrm{g}$ at $10 \mathrm{PW}$, then decreased to 3.89 and 2.61 $\mathrm{mg} / \mathrm{g}$ at $20 \mathrm{PW}$. Arabinose and trehalose had lower concentrations than glucomannan and mannan. Still, with a similar pattern to glucomannan and mannan, their concentrations increase to 2.9 and $5.94 \mathrm{mg} / \mathrm{g}$ at $6 \mathrm{PW}$, then decrease to 1.29 and $5.15 \mathrm{mg} / \mathrm{g}$ at $20 \mathrm{PW}$. Conversely, glucose and mannose were carbohydrate components with decrease concentrations to 20.22 and $15.79 \mathrm{mg} / \mathrm{g}$ at $6 \mathrm{PW}$, then increased to 33.91 and $31.27 \mathrm{mg} / \mathrm{g}$ at $20 \mathrm{PW}$, and galactose in which its concentrations decreased to $23.06 \mathrm{mg} / \mathrm{g}$ at $8 \mathrm{PW}$, then increased to $46.59 \mathrm{mg} / \mathrm{g}$ at $20 \mathrm{PW}$ (Figure 2).

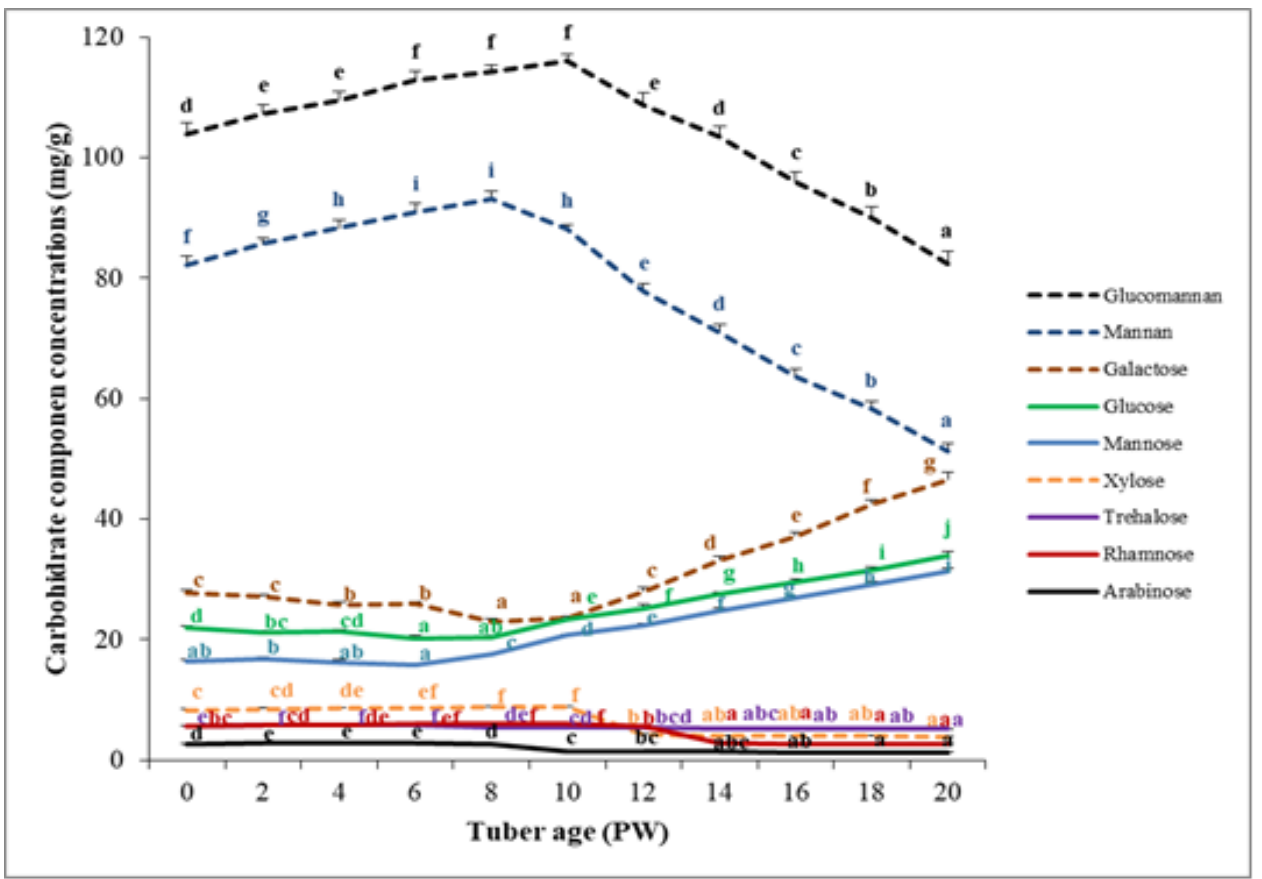

Figure 2.

Concentration of carbohydrate components in post-harvest porang tubers

PW: postharvest week, the same letter notation ( $a, b, c$ and d) in each carbohydrate component showed no significant difference $(p=0.05)$, bar $=$ standard error $(S E)$

The difference in carbohydrate component concentrations in porang tubers was affected by postharvest age. The concentration of carbohydrate components in the tubers is prompted by environmental conditions, maturity at harvest, and postharvest age-related to metabolic activity [31]. In the process of respiration, substrates with more complex molecules are broken down into simple sugars to enter the respiratory pathway to provide energy for plants [33]. During postharvest, the process of starch degradation by the $\alpha$-amylase enzyme into simple sugars causes an increase in glucose concentrations in sweet potatoes [20,31]. In addition to starch degradation, degradation of complex carbohydrates such as sucrose, glucomannan and trehalose might cause an increase in glucose in postharvest tubers [44]. Glucose is one of the substrates used for respiration, and together with oxygen, they are converted into carbon dioxide, water and energy. This respiration energy is used to grow sprouts and another cell needs [3, 44].
Glucomannan and mannan concentrations in porang tuber older than $10 \mathrm{PW}$ were decreased (Figure 2). This decline might be due to the degradation of glucomannan into mannose and glucose and mannan degraded into 2 molecules of mannose. It contributes to an increase in postharvest mannose and glucose. In A. konjac tubers, decreased concentration of postharvest glucomannan and mannan occurs due to the degradation of glucomannan into glucose and mannose and mannan into 2 mannose molecules by the enzymes $\beta$-mannanase, $\beta$-mannosidase and $\beta$-glucosidase $[28,37]$. In addition, this change might be influenced by the development of the tubers during the dormancy period. Glucomannan concentration of $A$. konjac tubers in dormancy periods was high, whereas in bud periods appeared low [15]. Differences in glucomannan concentrations in tubers might be caused by genetic factors, growth stage, postharvest age and environment (temperature, $\mathrm{CO}_{2}$ availability and light) [6, 24]. 
Trehalose concentration in porang tubers was very low and gradually decreased to $20 \mathrm{PW}$ (Figure 2). It possibly is due to trehalose's degradation to 2 glucose molecules, inducing an increase in postharvest glucose concentration. Trehalose in plants is found in small amounts, but it has an important role in the growth, development, and synthesis of starch [18]. Trehalose activates the enzyme Adenoside-5-diphosphoglucose pyrophosphorylase (AGPase) through post-translational activation to synthesize starch [22]. Correlation between increased $\alpha$-amylase activity with decreased starch content and increased glucose was observed in the postharvest period of sweet potatoes. The increase in glucose concentration was due to the degradation of sucrose [43]. Sucrose in plants has the same function as trehalose. Hydrolysis of trehalose by the trehalase enzyme into two glucose molecules produces ATP that will be used for further molecular synthesis [4, 22]. In this study, a decrease in trehalose concentration followed by an increase in glucose might be related to a decrease in starch concentrations in postharvest porang tubers.

The concentration of xylose, arabinose and rhamnose in porang tubers was low, and they decreased to 3.89 $\mathrm{mg} / \mathrm{g}$ at $20 \mathrm{PW}$ (Figure 2). Xylose, arabinose, and rhamnose were found in small amounts, about 5 $10 \%$ in Arabidopsis [45]. Decreasing of xylose, arabinose and rhamnose concentrations in postharvest porang tubers were presumably because those components did not play a role in the sprouting process; hence, the tubers would not synthesize them again.

Glucose, galactose, and mannose concentrations in postharvest porang tubers were quite high and tended to increase to $30.91,46.59$ and $31.27 \mathrm{mg} / \mathrm{g}$ at $20 \mathrm{PW}$, respectively (Figure 2). The increase in glucose and mannose concentration may result from degradation of glucomannan, mannan and trehalose to supply energy for sprout growth. Meanwhile, increased concentrations of galactose might be the result of the degradation of lactulose or lactose. Galactose is one of the monosaccharides that make up these two carbohydrate components [26]. However, the two carbohydrate components were not detected by HPLC analysis. Thus, a further investigation was needed to detect other carbohydrate components in the porang tubers. The hydrolysis of starch to simple sugars causes increased glucose, mannose and galactose concentrations in postharvest Dioscorea tubers by the enzyme amylase $[14,26,31]$. Besides starch degradation, the increase in postharvest monosaccharides resulted from the degradation of other carbohydrate components such as maltose, sucrose, glucomannan, mannan and trehalose. Glucose, galactose and mannose are included in monosaccharides which play an important role in sprout growth. Thus, their concentrations increase during postharvest [29]. The stage of growth influences the concentration of carbohydrate components in tubers, tuber maturity at harvest, postharvest handling and environmental stress [31, 32, 34].

Relationship between weight loss, water content and carbohydrate component in postharvest porang tubers Weight loss in postharvest porang tubers had a negative correlation $(-0.97 * *)$ with water content. It indicated that the higher the weight loss, the lower the water content in postharvest porang tubers. In previous studies, weight loss of porang tubers up to $14 \mathrm{PW}$ had a negative correlation with water content with the value of $-0.38 * *$ [1]. This difference was due to the postharvest age. The correlation value of tubers aged 0 - 20 PW was higher than tubers aged 0 - 14 PW. It was because the tubers aged $20 \mathrm{PW}$ had a higher weight loss and lower water content than the tubers of $14 \mathrm{PW}$; therefore, the correlation value was affected as well. Nevertheless, the magnitude of the correlation value of weight loss and water content in postharvest porang tubers could be closely related to the process of respiration and transpiration. During respiration, oxygen absorbed from the air together with carbohydrates (sugar) is converted into $\mathrm{CO}_{2}$, water, and energy in the form of heat. This process of breaking down starch into simple sugars causes the reduction of tubers' dry matter, increasing postharvest weight loss. Meanwhile, the transpiration process causes water to evaporate through the skin resulting in a decrease in water content [5, 17].

The correlation of weight loss with each component of carbohydrate is different. A positive correlation occurred between weight loss and carbohydrate component levels such as glucose, galactose and mannose. It means the higher weight loss, the higher the glucose, galactose and mannose levels. Meanwhile, a negative correlation occurred between weight loss and other carbohydrate components i.e. xylose, arabinose, rhamnose, trehalose, mannan and glucomannan. It indicates that the higher the weight loss, the lower the xylose, arabinose, rhamnose, trehalose, mannan and glucomannan concentration. The strongest correlation between weight loss and carbohydrate component was weight loss and mannose $\left(-0.88^{* *}\right)$. Such difference was caused by loss of water due to the process of respiration, transpiration and degradation of carbohydrates into simple sugars. Loss of water in the tubers causes an increase in weight loss [32]. The degradation of glucomannan, mannan and trehalose into simple sugars is useful for energy growth and sprouting. It causes a decrease of xylose, arabinose, rhamnose, trehalose, mannan and glucomannan and increase of glucose, galactose and mannose in postharvest. Starch degradation in postharvest yam tubers caused a decrease in tuber weight and an increase in reducing sugars, especially glucose for sprout growth energy [5, 28].

The correlation test between water content and carbohydrate component presented an alteration of correlation. A positive correlation occurred between water content and xylose, arabinose, rhamnose, trehalose, mannan 
and glucomannan, whereas the negative one occurred between water content and glucose, galactose and mannose. It means the lower the water content, the higher the glucose, galactose and mannose level, whereas the lower the water content, the lower xylose, arabinose, rhamnose, trehalose, mannan and glucomannan level. The strongest correlation was between water content mannose (-0.88**). Our study supposes that the difference in correlation value was influenced by the degradation process of complex molecules into simple sugars, respiration and postharvest transpiration. Decreased water content in postharvest potato tubers was driven by respiration and transpiration processes [7]. In contrast, changes in carbohydrate components in sweet potatoes were urged by the activity of the amylase enzyme in degrading starch, causing starch reduction and increasing glucose and fructose [44]. In addition, the decrease in water content followed by changes in the content of carbohydrate components was affected by the nature of the carbohydrate component. Trehalose is known as water entrapment, which plays a role in binding water. Trehalose has the ability to form hydrogen bonds with biological material and form hydrogen bonds with water [23]. In this study, a decrease in trehalose concentrations decreased the ability to absorb water so that the water content in porang tubers also decreased. Therefore, it was presumably that xylose, arabinose, rhamnose, mannan and glucomannan also had the same role as trehalose [11, 32].

Variation of correlation among carbohydrate components was also evident. Negative correlations were observed between xylose, arabinose and rhamnose with glucose, galactose and mannose, glucose, galactose, mannose with trehalose, mannan and glucomannan, while positive correlations were observed between xylose with arabinose, rhamnose, trehalose, mannan and glucomannan. A positive correlation was also observed between arabinose with trehalose, mannan and glucomannan; rhamnose with trehalose, mannan and glucomannan; glucose with galactose and mannose; galactose with mannose; trehalose with mannan and glucomannan; and mannan with glucomannan. It means that the lower the concentrations of xylose, arabinose, rhamnose, trehalose, mannan and glucomannan, the higher the concentration of glucose, galactose and mannose in tubers of postharvest porang, while the higher the concentration of xylose, the higher the concentration of arabinose, rhamnose, trehalose, mannan and glucomannan. The strongest correlation among the carbohydrate components was found between glucose and mannose $(0.99 * *)$. These differences might be influenced by the metabolism of each postharvest carbohydrate component. Polysaccharides and disaccharides degraded to monosaccharides lead to the decrease of glucomannan, mannan and trehalose, followed by an increase in monosaccharides especially glucose, galactose and mannose. Meanwhile, a decrease in monosaccharides (xylose, arabinose and rhamnose) might be affected by un-synthesized carbohydrates in postharvest tubers since they were not used as energy for growth. The differences of the correlation value of carbohydrate components concentration were related to water content, metabolic activity and temperature. Room temperature affects the process of respiration and degradation of carbohydrates to sugar [30, 44]. The age of postharvest tubers impacts the changes in carbohydrate component concentrations in porang tubers.

The results of this study indicated that the dynamics of weight loss, water content and carbohydrate components in postharvest porang tubers could be used to determine the time or age of postharvest tubers for industrial materials. The maximum of $10 \mathrm{PW}$ was the best time for tubers to be processed for industrial purposes because of their high glucomannan levels. Meanwhile, tubers older than $10 \mathrm{PW}$ contained lower water levels, weight, xylose, arabinose, rhamnose, trehalose, mannan, glucomannan and increased glucose, galactose and mannose as a sign of decreased tuber quality. Changes in postharvest weight, water content and carbohydrate components of tubers might be influenced by the process of respiration and transpiration. Thus, the factors influencing the changes in postharvest tubers reducing tuber quality are necessary to investigate further.

\section{Conclusions}

The postharvest period increases the weight loss, decreases the water content, xylose, arabinose, rhamnose, trehalose, mannan and glucomannan concentration and increases the glucose, galactose and mannose concentration in porang tubers. Among the nine carbohydrate components identified, glucomannan was the carbohydrate component with the highest concentrations. Based on a gradual increase in glucomannan concentrations until $10 \mathrm{PW}$ and subsequently continued to decrease until $20 \mathrm{PW}$, it is inferred that good quality tubers for the pharmaceutical industry could be obtained at the age of no more than $10 \mathrm{PW}$.

\section{Acknowledgement}

The authors thank the Postgraduate Domestic Education Scholarship (BPPDN), the Ministry of Education and Culture, the Porang Research Center (PRC) Brawijaya University, East Java, Indonesia, and then Tanjungpura University for supporting this research.

\section{Conflict of interest}

The authors declare no conflict of interest.

\section{References}

1. Adawiyah PRA, Physical and chemical Changes of porang tubers (Amorphophallus muelleri Blume) based on location and duration of storage. Department of Biology, Faculty of Natural Mathematics and Natural Sciences, Brawijaya University, Malang, Thesis, 2018. 
2. Afek U, Kay S, Postharvest physiology and storage of widely used root and tuber crops. Hortic Rev., 2004; 30: 253-316.

3. Aksenova NP, Sergeeva LI, Konstantinova TN, Golyanovskaya SA, Kolachevskaya OO, Romanov GA, Regulation of potato tuber dormancy and sprouting. Russ J Plant Physiol., 2013; 60(3): 301-312.

4. Aleel KG, The role of trehalose biosynthesis in plants. Plant Physiol., 2007; 144: 3-5.

5. Andreas TB, Controlling post-harvest losses of yam (Dioscorea spp) by aplication of gibberelic acid, ETH Zurich Research Collection, Thesis, 2003.

6. Arumingtyas EL, Fatinah AA, Sequence variation of CSLA gene responsible for the synthesis of glucomannan in porang (Amorphophallus muelleri Blume) collected from Java, Indonesia. J Life Sci Technol., 2015; 3(1): 7-10.

7. Asgar A, Rahayu ST, Effect of storage temperature and conditioning time to maintain the quality of margahay cultivar potatoes. Berita Biologi, 2014; 13(3): 283-293.

8. Behera SS, Ray RC, Konjac glucomannan, a promising polysaccharide of Amorphophallus konjac K. Koch in health care. Int J Biol Macromol., 2016; 92: 942-956.

9. Casacchia T, Sofo A, Toma CC, Drăgănescu D, Tița B, Statti GA, Nutraceutical properties and healthpromoting biological activities of fruits of watermelon cultivars with different origins. Farmacia, 2020; 68(4): 679-687.

10. Cheema MUA, Dormancy and sprout control in root and tuber crops. Natural Resources Institute, University Of Greenwich UK, Thesis, 2010.

11. Craufurd P, Summerfield Q, Asiedu RJR, Prasad, PVV, Dormancy in yams. Exp Agric., 2001; 37: 147-181.

12. Dhua RS, Ghosh SK, Biswas J, Mitra SK, Sen H, Effect of some chemicals on sprouting, growth and corm yield of Amorphophallus campanulatus. J Root Crops, 1988; 14: 47-49.

13. Edmunds B, Boyette M, Clark C, Ferrin D, Smith T, Holmes G, Postharvest Handling of Sweetpotatoes. Nort Carolina State University, 2008; 413: 7-53.

14. Ekowati G, Yanuwiyadi B, Azrianingsih R, Source of Glucomannan from edible Araceae in East Java. Ind J Environ Sustain Dev., 2015; 6(1): 32-41.

15. Gille S, Cheng K, Skinner ME, deep sequencing of voodoo lily (Amorphophallus konjac): An approach to identify relevant genes involved in the synthesis of the hemicellulose glucomannan. Planta, 2011; 234: 515-526.

16. Gusmalawati D, Arumingtyas EL, Azrianingsih R, Mastuti R, LC-MS analysis of carbohydrate components in Porang tubers (Amorphophallus muelleri Blume) from the second and the third growth period. IOP Conf Ser Earth Environ Sci., 2019; 391(1): 1-7.

17. Herianto E, Efendi R, Zalfiatri Y, The effect of time storage on characteristic of Dahlia tuber's. JOM Faperta, 2018; 5(1): 1-11.

18. Higashiyama T, Novel functions and applications of trehalose. Pure Appl Chem., 2002; 74(7): 1263-1269.

19. Holcroft D, Curing and storage of tropical roots, tubers and corms to reduce postharvest losses. PEF
White Paper No. 18-02, The Postharvest Education Foundation (PEF), 2018; 1-37.

20. Huang YH, Picha DH, Kilili AW, Johnson CE, Changes in invertase activities and reducing sugar content in sweetpotato stored at different temperatures. J Agric Food Chem., 1999; 47: 4927-4931.

21. Indriyani $S$, Growth patterns of porang (Amorphophallus muelleri Blume) and environmental influences on oxalate and glucomannan content, Postgraduate Program at Airlangga University, Surabaya, Dissertation, 2011.

22. Kolbe A, Tiessen A, Schluepmann H, Paul MJ, Ulrich $\mathrm{S}$, Geigenberger P, Trehalose 6-phospate regulates starch synthesis via posttranslational redox activation of ADPglucose pyrophosphorylase. Proc Natl Acad Sci., 2005; 102: 11118-11123.

23. Kotake $\mathrm{T}$, Yamanashi $\mathrm{Y}$, Chiemi Imaizumi C, Tsumuraya Y, Metabolism of 1-arabinose in plants. J Plant Res., 2016; 129: 781-792.

24. Lakitan B, Fundamentals of plant physiology, PT. Raja Grafindo Persada, Jakarta, 2008.

25. van der Maarel MJEC, van der Veen B, Uitdehaag JCM, Properties and applications of starch-converting enzymes of the alpha family. J Biotechnol., 2002; 94: 137-155.

26. Makanjuola, Moses O, Osinfade, Gbolahan B, Determination of sugars in yams under storage during the dry season. IOSR J Environ Sci Toxicol Food Technol., 2017; 11(11): 24-27.

27. Mani F, Aieb TB, Doudech N, Hannach C, Physiological mechanisms for potato dormancy release and sprouting: a Review. Afr Crop Sci J., 2014; 22(2): 155-174.

28. Martin K, Soumalia D, Lucien P, Effects of postharvest storage on some biochemical parameters of different parts of two yams species (Dioscorea spp). Afr J Food Sci., 2010; 1(1): 1-9.

29. Moreira LRS, Filho EXF, An overview of mannan structure and mannan-degrading enzyme systems. Appl Microbiol Biotechnol., 2008; 79: 165-178.

30. Muthoni J, Kabira J, Shimelis H, Melis R, Regulation of potato tuber dormancy: A Review. Aust J Crop Sci., 2014; 8(5): 754-758.

31. Nabubuya A, Namutebi A, Byaruhanga Y, Narvhus J, Wicklund T. Influence of development, postharvest handling, and storage conditions on the carbohydrate components of sweetpotato (Ipomea batatas Lam.) roots. Food Sci Nutr., 2017; 5(6):1088-1097.

32. Osunde ZD, Orhevba BA, Effects of storage conditions and storage period on nutritional and other qualities of stored yam (Dioscorea spp) tubers. Afr J Food Agric Nutr Dev., 2009; 9(2): 678-690.

33. Pringle B, Bishop C, Clayton R, Potetoes posharvest. CAB International, USA, 2009; 17-23.

34. Roessner U, Wagner C, Kopka J, Trethewey RN, Willmitzer L, Simultaneous analysis of metabolites in potato tuber by gas chromatography-mass spectrometry. Plant J., 2000; 23: 131-142.

35. Sesta G, Determination of sugar in royal jelly by HPLC. Apidologie. Springer Verlag, 2006; 37(1): 84-90.

36. Sonnewald S, Sonnewald U, Regulation of potato tuber sprouting. Planta, 2014; 239: 27-38.

37. Sulistiyo RH, Lita S, Damanhuri, Exploration and identification of porang morphological character 
FARMACIA, 2021, Vol. 69, 6

(Amorphophallus muelleri B.) in East Java. J Plant Prod., 2015; 3(5): 353-361.

38. Sumarwoto, Iles-Iles (Amorphophallus muelleri Blume); Description and other properties. J Biodiversitas, 2005; 6(3): 185-190.

39. Sumarwoto, Review: Constituen of mannan of iles-iles (Amorphophallus muelleri Blume.). Bioteknologi, 2007; 4(1): 28-32.

40. Suttle JC, Physiological regulation of potato tuber dormancy. Am J Potato Res., 2004; 81: 253-262.

41. Tester R, Al-Ghazzewi F, Shen N, Chen Z, Chen F, Yang J, Tang M, The use of konjac glucomannan hydrolysates to recover healthy microbiota ininfected vaginas treated with an antifungal agent. Benef Microbes, 2012; 3: 61-66.
42. Yuzammi, Kurniawan A, Asih NPS, Erlinawati I, Hetterscheid W, The Amorphophallus of Indonesia. Center for Concervation Botanic Gardens Indonesia Institute of Sciences, 2017; 120-124.

43. Zhang YQ, Xie BJ, Gan X, Advance in the applications of konjac glucomannan and its derivatives. Carbohydr Polym., 2005; 60: 27-31.

44. Zhang Z, Wheatley CC, Corke H, Biochemical changes during storage of sweet potato roots differing in dry matter content. Postharvest Biol Technol., 2002; 24: 317-325.

45. Zhao C, Zayed O, Zeng F, Liu C, Zhang L, Zhu P, Hsu CC, Tuncil YE, Tao WA, Carpita NC, Zha JK, Arabinose biosynthesis is critical for salt stress tolerance in Arabidopsis. New Phytol., 2019; 224: 274-290. 